\title{
The Effect of the Global Financial Crisis on the Level of Accounting Conservatism in Commercial Banks: Evidence from Jordan
}

\author{
Yusuf Ali Khalaf Al-Hroot ${ }^{1}$, Laith Akram Muflih Al -Qudah ${ }^{2}$ \& Faris Irsheid Audeh Alkharabsha ${ }^{3}$ \\ ${ }^{1}$ Department of Accounting, Faculty of Administrative \& Financial Sciences, Philadelphia University, Amman, \\ Jordan \\ ${ }^{2}$ Al-Balqa Applied University (Amman University College for Financial \& Administrative Sciences), Amman, \\ Jordan \\ ${ }^{3}$ Al-Balqa Applied University, Salt, Jordan \\ Correspondence: Yusuf Ali Khalaf Al-Hroot, Assistant Professor, Department of Accounting, Faculty of \\ Administrative \& Financial Sciences, Philadelphia University, Jordan. PO Box: 19392, Amman, Jordan. E-mail: \\ yhroot@philadelphia.edu.jo
}

Received: December 19, 2016

Accepted: January 20, 2017

Online Published: January 26, 2017

doi:10.5539/ijbm.v12n2p151

URL: http://dx.doi.org/10.5539/ijbm.v12n2p151

\begin{abstract}
This paper intends to investigate whether the financial crisis (2008) exerted an impact on the level of accounting conservatism in the case of Jordanian commercial banks before and during the financial crisis. The sample of this study includes 78 observations; these observations are based on the financial statements of all commercial banks in Jordan and may be referred to as cross-sectional data, whereas the period from 2005 to 2011 represents a range of years characterized by time series data. The appropriate regression model to measure the relationship between cross-sectional data and time series data is in this case the pooled data regression (PDR) using the ordinary least squares (OLS) method. The results indicate that the level of accounting conservatism had been steadily increasing over a period of three years from 2005 to 2007. The results also indicate that the level of accounting conservatism was subjected to an increase during crisis period between 2009 and 2011 compared with the level of accounting conservatism for the period 2005-2007 preceding the global financial crisis. The F-test was used in order to test the significant differences between the regression coefficients for the period before and during the global financial crisis. The results indicate a positive impact on the accounting conservatism during the global financial crisis compared with the period before the global financial crisis. The p-value is 0.040 which indicates that there are statistically significant differences between the two periods; these results are consistent with the results in Sampaio (2015).
\end{abstract}

Keywords: global financial crisis, accounting conservatism, commercial banks, Jordan

\section{Introduction}

The global financial crisis started to show its effects after the first half of 2007 and throughout 2008. In some countries, the effects of the financial crisis became apparent in 2009. The financial crisis that overthrew the monetary system and banking sector in late 2008 in the United States had exerted a significant impact on most U.S. economic sectors, and the effects thereof propagated across various countries worldwide in varying degrees. In 2008, the financial crisis expanded to Jordan and its effects are still felt to this day.

The financial crisis is likely to have an impact on financial reporting, but it is difficult to verify its magnitude exactly. Jordan is a small Arab country which stands at the crossing point between Europe, Asia and Africa, characterized by a stable political and democratic environment (Amman Stock Exchange [ASE], 2010). Poverty, unemployment, inflation, and insufficient supplies of water, oil, and other natural resources constitute the fundamental economic problems in Jordan. This paper aims to investigate whether the financial crisis exerted an impact on the level of accounting conservatism in the case of Jordanian commercial banks.

The prominent effect of accounting conservatism on the accounting information which is reflected on the decisions taken in light of such information resulted in an increase in terms of accounting research especially over the course of the last decade. This accounting conservatism is considered to be among the important principles that affect the consistency and accuracy of the accounting information listed in the financial lists. 
However, there are various aspects which stirred the interest of scholars in accounting conservatism, including the need to have more conservative financial lists in order to ensure the existence of profit management practices in financial reports, the dissemination of debates about the use of fair value in evaluating the assets which indicate the need for a disclosure thereof when taking consultation decisions (Mohammed, 2011). Accounting conservatism is defined as the differential verifiability required for the recognition of profits versus losses (Basu, 1997). Chung and Wynn (2008) defined accounting conservatism as a decrease in the company's value of net assets, prevention of potential risks and consequences resulting from lawsuits, and the presentation of more accurate data for all parties. FASB (1980) defined accounting conservatism as a delay in recognizing the revenues in case of uncertainty, and decrease instead of exaggeration in evaluating the assets and profits during the current period, not to forget acknowledging any potential losses.

The relationship between a financial crisis and accounting conservatism was previously examined in the relevant body of literature. For example, Vichitsarawong et al. (2010) and Gul et al. (2002) both looked into the effect of the Asian financial crisis on the use of accounting conservatism. They found that conservative reporting decreased during the crisis period. Van der Heijden (2012) did not identify any differences between the levels of conservatism prior and during the crisis across seven European countries.

The rest of the paper is organized as follows: The second section provides a review of the most relevant existing publications. The third section presents the objective of the study. The fourth section presents and discusses the empirical results. The last section concludes the study.

\section{Literature Review}

In view of the extensive research studies conducted in relation to accounting conservatism, it can be concluded that there are several measures used to in order to assess accounting conservatism, namely the earnings/stock return relation measures, income statement measures and balance sheet measures. One of the main papers within the current body of literature on conservatism is Basu's (1997) research on conservatism and the asymmetric timeliness of earnings. Basu interprets conservatism as the accountants' tendency to require a higher degree of verification in order to recognize good news as gains and bad news as losses. The study conducted by Hamdan (2011) sought to evaluate the level of accounting conservatism upon preparing the financial data for the companies listed in the Kuwait Stock Exchange and adding the following factors: size of the company, debt contract, and type of sector. In order to achieve the objective of the study, the Basu model (1997) was used, with the results of the study indicating that the level of accounting conservatism was very high.

Balakrishnan et al. (2015) investigated the effect of accounting conservatism on firm-level investment over the course of the financial crisis between 2007 and 2008). It was found that firms were characterized by a low accounting conservatism before the crisis and that there was a negative relationship between debt raising activities and stock performance. Herrmann et al. (2008) examined the relationship between the Asian financial crisis and the level of accounting conservatism in the case of Thai companies. The result of the study suggested a low level of accounting conservatism prior to the Asian financial crisis compared to the period during the Asian financial crisis. Sampaio (2015) examined the relationship between conservatism and the crisis sensitivity of countries. By using Basu's (1997) model and Khan and Watss' (2009) C-score model, the research study concluded that there is a statistically significant and positive association between conservatism and financial crises. Furthermore the study of Gul et al. (2002) found that the level of conservatism decreased statistically significantly during the period of the crisis. Hamdan (2012) found that the level of accounting conservatism in the financial reports issued by Jordanian companies remained low for the period between 2002 and 2006 . Furthermore, it was also found that the banking sector in Jordan was the most developed industry compared with other sectors. The study of Francis et al. (2013) suggests that there is a relation between accounting conservatism and the performance of firm stock and that this relation is significantly positive over the course of the global financial crisis. Another study examined the impact of the financial crisis on accounting conservatism in the Netherlands. Leune (2014) found that Dutch listed companies were not asymmetrically sensitive to losses and gains prior to the crisis. During the crisis period, companies became non-conservative. This indicates that earnings became more sensitive to gains than to losses during the financial crisis. In addition, the study of Warganegara and Vionita (2010) examined the effects of the Asian financial crisis on the levels of accounting conservatism in Indonesia. This study found that during the post-crisis period, although there is evidence to suggest that stock returns led earnings and that accruals were utilized properly in noise reductions, accounting practices in Indonesia nevertheless did not exhibit the accepted level of conservatism.

To summarize, there is a lack of evidence from previous research studies regarding the impact of the global financial crisis of 2008 on accounting conservatism. Additionally, previous research about accounting 
conservatism was conducted in countries outside Asia such as the USA, the UK or other members of the European Union. Furthermore, Beaver provided the five important areas and modern research directions for accounting, namely earnings management, corporate governance, quality accounting profits, quality audits, contractual relationships and lawsuits. Most topics provided by Beaver are related to the measurement of accounting conservatism, while a scarcity of research in this area of scientific research related to Jordan in particular may be found. The subject of measuring accounting conservatism in Jordanian commercial banks is a very important topic in order to identify the level of accounting conservatism for profits in the banks. Thus accounting conservatism is important for the protection of investors, creditors, and capital owners, because the accounting information is used as an important basis for making investment and credit decisions on the part of investors and shareholders, and other parties.

\section{Objectives of the study}

The main objective of the study is to measure the effect of the global financial crisis on the level of accounting conservatism in the case of Jordanian commercial banks using the Basu model. Figure 1 below shows the variables of the study.

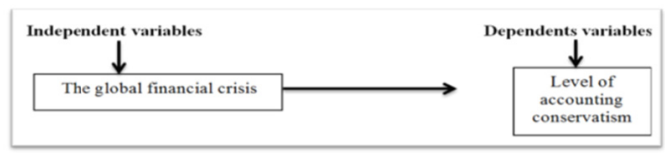

Figure 1. Variables of the study

\section{Hypotheses}

Based on the development of the concept and framework given above, we state our hypotheses as follows:

$\mathbf{H}_{\mathbf{0}}$ : There is no statistically significant difference in the level of accounting conservatism prior to the global financial crisis compared to the level of accounting conservatism during the global financial crisis in the case of commercial banks in Jordan.

\section{Methodology}

\subsection{The Basu Conservatism Metric}

The metric of Basu (1997) is one of the most widely used models for measuring accounting conservatism in financial statements. The Basu model is investigated in this study in order to obtain evidence related to the extent of the change in conservatism in the Jordanian banking sector. Accounting conservatism is measured as the extent to which bad news (negative returns) are reflected in reported earnings more rapidly than good news (positive returns). Basu's formula may be expressed as:

$$
\mathrm{X}_{\mathrm{it}} / \mathrm{P}_{\mathrm{it}-1}=\alpha+\beta_{1} \mathrm{R}_{\mathrm{it}}+\beta_{2} \mathrm{DR} \mathrm{R}_{\mathrm{it}}+\beta_{3}\left(\mathrm{R}_{\mathrm{it}} * \mathrm{DR} \mathrm{R}_{\mathrm{it}}\right)+\varepsilon_{\mathrm{it}}
$$

$\mathrm{X}_{\mathrm{it}}$ : earnings per share for company (i) in year $(\mathrm{t})$.

$P_{i t-1:}$ per share price in the beginning of the fiscal year.

$\mathrm{DR}_{\mathrm{it}}$ : the return on company (i) for one year.

$\mathrm{R}_{\mathrm{it}}$ : dummy variable.

cit: error cannot be interpreted by model.

We used the regression model before and during the crisis in order to draw a comparison between the two periods previously defined.

As stated earlier, the variable returns $\left(\mathrm{DR}_{\mathrm{it}}\right)$ in the model records all positive and negative market returns indifferently. The variable news $\left(R_{i t}\right)$ is a dummy variable which takes the values one or zero. The $\left(D_{i t}\right)$ separates the negative returns which take the value of one and the positive returns which take the value of zero. If we multiply variable $\left(\mathrm{R}_{\mathrm{it}}\right)$ with variable $\left(\mathrm{DR}_{\mathrm{it}}\right)$, the output of the previous multiplication will create new independent variables referred to as $\left(\mathrm{R}_{\mathrm{it}} \times \mathrm{DR}_{\mathrm{it}}\right)$ and take the negative return values only. $\left(\beta_{1}\right)$ measures the coefficient regression of positive returns only, while $\left(\beta_{3}\right)$ measures the coefficient regression of negative returns. $\left(\beta_{2}\right)$ measures accounting conservatism in the financial statements and these returns take either positive or negative values. In his study, Basu (1997) explained that if this factor takes a negative value it expresses the level of accounting conservatism regardless of the values of the negative returns. 


\subsection{Data Analysis and Results}

The sample of this study includes 78 observations; these observations are based on the financial statements of all commercial banks in Jordan and incorporate cross-sectional data, while the period from 2005 to 2012 represents a range of years characterized by time series data. The appropriate regression model to measure the relationship between cross-sectional data and time series data in this case the pooled data regression (PDR) using the ordinary least squares (OLS) method.

Before starting the estimation regression models and testing the hypotheses, we must verify the validity of data in the first stage; this is achieved through a series of tests:

\section{The normal distribution test}

In order to determine whether the data is normally distributed we used the Jarque-Bera (J-B) test. The null hypothesis $\left(\mathrm{H}_{0}\right)$ for the J-B is that the data is normally distributed if the probability of the J-B test is greater than 0.05 ; otherwise, the null hypothesis is discarded. As shown in Table 1, the probability of (J-B) for all variables in the model is less than 0.05 , which means that the variables are not normally distributed. In order to solve this problem we must transform the variables into a natural logarithm in order to obtain a more normal distribution.

\section{Testing the stability of time-series}

As in the current study, the applied research method using time series assumes the stability of those series. The autocorrelation arises in the model due to unstable time series (Gujarati, 2003). In order to investigate the stability of the time series the unit root test including the parametric augmented Dickey-Fuller test (ADF), and the non-parametric Phillips-Perron (PP) test was used for this purpose. Table 1 shows that the critical values of the $\mathrm{ADF}$ at the $1 \%$ and $5 \%$ levels are -1.237 and -2.241 respectively, whereas the p-value for the 91 observations is 0.361 . The $\mathrm{p}$-value is greater than the critical values, which is indicative of the fact that the null hypothesis has been accepted and that the time series data remained stable for the period 2005 to 2012.

\section{Multicollinearity test}

The collinearity diagnostics are used in order to measure the multicollinearity. The tolerance coefficient for each variable of the independent variables is calculated in order to determine the VIF coefficient. If the VIF value is higher than 5 it is indicative of a high independent variable correlation problem as shown in Table 1. If the VIF value for all the independent variables is less than 5, this is indicative of a lack of multicollinearity among the factors of the study model.

\section{Autocorrelation test}

The Durbin Watson (DW) test was used in order to measure the autocorrelation problem, with a DW range between 0 and 4. Furthermore, if the DW value is less than 1.5, this indicates that there is a positive autocorrelation in the residuals of a time series. Conversely, if the DW value is greater than 2.5 , this means that a negative correlation has been identified. Otherwise, if the DW value ranges between 1.5 and 2.5 , it may be inferred that the study model is free from autocorrelation problems. As indicated in Table 1, the value of the DW for the model of study is 1.89 . This value falls between 1.5 and 2.5 , which means that no autocorrelation problem was detected.

Table 1 . Testing the validity of data for statistical analysis

\begin{tabular}{|c|c|c|c|c|}
\hline \multirow[t]{2}{*}{ Variable } & \multicolumn{2}{|c|}{$\begin{array}{l}\text { Normal Distribution } \\
\text { (Jarque Bera test) }\end{array}$} & \multicolumn{2}{|c|}{ Times series test } \\
\hline & $\mathrm{J}-\mathrm{B}$ & Sig.* & $\mathrm{ADF}$ & PP \\
\hline Xit & 625 & 0.000 & 8.555 & 9.654 \\
\hline $\mathrm{Pi}, \mathrm{t}-1$ & 486 & 0.000 & 7.450 & 8.241 \\
\hline $\mathrm{Ri}, \mathrm{t}$ & 168 & 0.000 & 7.883 & 8.124 \\
\hline \multirow[t]{2}{*}{ Variable } & \multicolumn{2}{|c|}{$\begin{array}{l}\text { Multicollinearity } \\
\text { (Collinearity test) }\end{array}$} & \multirow{2}{*}{\multicolumn{2}{|c|}{$\begin{array}{l}\text { Autocorrelation } \\
\text { (Durban Watson test) }\end{array}$}} \\
\hline & VIF & Tolerance & & \\
\hline DRi,t & 1.213 & 0.824 & & \\
\hline $\mathrm{Ri}, \mathrm{t}$ & 1.025 & 0.975 & DW & 1.84 \\
\hline $\mathrm{DRi}, \mathrm{t} \times \mathrm{Ri}, \mathrm{t}$ & 1.077 & 0.928 & & \\
\hline
\end{tabular}

\footnotetext{
* Test at the $5 \%$ level of significance.
} 


\subsubsection{Descriptive Statistics for Sample}

Table 2 shows the descriptive statistics for the full sample. The mean, standard deviation, variances, median, minimum value, maximum value, first and third quartiles, interquartile range (IQR) and natural logarithm (log $\left.\left(\mathrm{R}_{\mathrm{it}}\right)\right)$ are reported. The distributions are similar to those reported in the previous literature, such as Ettredge and Huang (2012) and Khan and Watts (2009).

Table 2. Descriptive statistics for the full sample

\begin{tabular}{llll}
\hline Variable & EPS & $\mathrm{R}_{\mathrm{it}}$ & $\log \left(\mathrm{R}_{\mathrm{it}}\right)$ \\
\hline Mean & 0.336 & 42093104.38 & 7.310 \\
St. Dev & 0.235 & 71034236.057 & 0.490 \\
Variance & 0.056 & $5.04586 \times 10^{\wedge} 15$ & 0.240 \\
Min & 0.096 & 2597203 & 6.415 \\
Q1 & 0.178 & 11588081 & 7.063 \\
Median & 0.214 & 17642520 & 7.246 \\
Q3 & 0.471 & 31100543 & 7.482 \\
Max & 4.039 & 82660083 & 8.425 \\
IQR & 0.340 & 5718252 & 0.136 \\
\hline
\end{tabular}

In order to test the hypothesis Basu's model was used to measure the level of conservatism in the case of the Jordanian commercial banks listed in the Amman Stock Exchange between 2005 and 2012, and to generally test the different levels of accounting conservatism before and during the world crisis in 2008.

In a first stage, we will test Basu's model on two sub-samples; the first sub-sample is the period preceding the world crisis spanning from 2005 to 2008, whereas the second sub-sample is the period during the world crisis spanning from 2009 to 2012. The additional response of bad news compared with the good news is measured in terms of the regression coefficient $\left(\beta_{1}\right)$ of the variable $(R * D R)$.

Basu's model was used in order to calculate the regression coefficient for each year of the study, and then the average of each of the first three years preceding the crisis $(2005,2006$ and 2007) was compared to the average of the last three years over the course of the crisis $(2009,2010$ and 2011) in order to test the difference between the two groups (pre- and during the world crisis) and to determine whether there is a statistically significant change in the level of accounting conservatism during the two periods (pre- and during the world crisis).

In the conservatism reporting it was expected for the coefficients of variables $(\mathrm{DR},(\mathrm{R} \times \mathrm{DR}))$ and of the constant to be positive. As for the coefficients $\left(\beta_{2+} \beta_{3}\right) / \beta_{2}$, these are expected to be greater than one, which measures the difference in terms of the sensitivity of earnings to bad news and good news. If the amount of the index is greater than one, it suggests that the earnings are sensitive to bad news compared with the good news. Furthermore, the coefficient $\left(\beta_{3}\right)$ of variable $(\mathrm{R} \times \mathrm{DR})$ should be higher for in the case of the period during the global financial crisis as opposed to the pre-period. Furthermore, the ratio should also be relatively high.

Table 3. Regression analysis for years before crisis

\begin{tabular}{|c|c|c|c|c|c|c|c|}
\hline Year & Variables & $\alpha$ & $\mathrm{R}_{\text {it }}\left(\beta_{1}\right)$ & $\mathrm{DR}_{\mathrm{it}}\left(\beta_{2}\right)$ & $\mathrm{R}_{\mathrm{it}} \times \mathrm{DR}_{\mathrm{it}}\left(\beta_{3}\right)$ & $\mathrm{R}^{2}$ & Adjusted $\mathrm{R}^{2}$ \\
\hline \multirow{3}{*}{2005} & Coefficient & 0.430 & -0.051 & -0.333 & 0.261 & \multirow{3}{*}{$8.10 \%$} & \multirow{3}{*}{$4.93 \%$} \\
\hline & t-value & 0.876 & 0.815 & 0.91 & 0.456 & & \\
\hline & p-value & 0.161 & -0.255 & -0.122 & 0.784 & & \\
\hline \multirow{3}{*}{2006} & Coefficient & 0.588 & -0.530 & -1.465 & 0.185 & \multirow{3}{*}{$12.25 \%$} & \multirow{3}{*}{$9.22 \%$} \\
\hline & t-value & 0.063 & 0.428 & 0.248 & 0.487 & & \\
\hline & $\mathrm{p}$-value & 0.550 & -0.677 & -1.286 & 0.263 & & \\
\hline \multirow{3}{*}{2007} & Coefficient & -1.531 & 0.086 & 1.177 & 0.168 & \multirow{3}{*}{$21.15 \%$} & \multirow{3}{*}{$18.43 \%$} \\
\hline & t-value & 0.528 & 0.599 & 0.656 & 0.713 & & \\
\hline & $\mathrm{p}$-value & -0.657 & 0.545 & 0.461 & 0.380 & & \\
\hline
\end{tabular}

Table 3 illustrates the coefficient of ( $\beta 3$ ) as a measure of the bad news responses to profits compared with the good news. The results indicate that the responses for the years 2005, 2006 and 2007 are positive and not significant. The p-value for the years 2005,2006 and 2007 is $0.784,0.263$ and 0.380 , respectively. The results indicate that the $(\beta 3)$ was increasing during the three years from 2005 to 2007, yet it does not indicate a significant change in the level of accounting conservatism in the years 2005, 2006 and 2007. Furthermore, the 
level of accounting conservatism (adjusted $\mathrm{R}^{2}$ ) increased from $4.93 \%$ in 2005 to $18.43 \%$ in 2007 in line with the decrease in the growth rate in Jordan. Year 2006 represents a stable year for the Jordanian economy as a whole and for the banking sector in particular. The rate of growth in total capital, reserves and provisions in the case of Jordanian commercial banks for the year 2006 was $41.32 \%$. In 2007, the growth rate decreased to $10.67 \%$, whereas towards the end of 2008 (the year of the global financial crisis) the growth rate decreased to 7.96. The growth rate recorded in 2008 is the lowest percentage in the last years due to the global financial crisis (The Association of Banks in Jordan, 2013).

Table 4. Regression analysis for the period (2005-2008)

\begin{tabular}{llll}
\hline Variables & Coefficient & t-value & p-value \\
\hline$\alpha$ & 0.321 & 0.644 & 0.331 \\
$\beta_{1}$ & -0.042 & 0.550 & -0.613 \\
$\mathrm{~B}_{2}$ & -0.435 & 0.589 & -0.416 \\
$\mathrm{~B}_{3}$ & 0.277 & 0.117 & 1.611 \\
$(\beta 1+\beta 3) / \beta 1$ & 1.28 & & \\
$\mathrm{R}^{2}$ & 10.8 & & \\
Adjusted $\mathrm{R}^{2}$ & $7.62 \%$ & & \\
\hline
\end{tabular}

Table 4 reports the results of the regression analysis for the period leading to the global financial crisis. As expected, the constant variable coefficient $(\alpha)$ and variable $\left(\beta_{3}\right)$ are positive, with a value of 0.321 and 0.277 , respectively. Variable $\beta_{3}(\mathrm{R} \times \mathrm{DR})$ is positive and statistically insignificant because the p-value is 0.117 and this is greater than 0.05 . On the other hand, the variable coefficient (DR) is unexpectedly negative and equal to -0.435 . Furthermore, the sensitivity of earnings to bad news (negative returns) is 1 to 1.28 times that of the sensitivity of earnings to good news (positive returns); $(-0.435+0.277) /-0.435))=1.28$ for the period 2005-2008. The adjusted $\mathrm{R}^{2}$ of the model is equal to $7.62 \%$, and from these results we can conclude that the level of accounting conservatism is low for the period 2005-2008.

The global financial crisis initially began in September 2008 and extended towards the end of 2009. The total growth rate of the deposits at the end of 2010 reached a rate of $9.8 \%$ from $7.96 \%$ in 2008 ; the central bank of Jordan stopped issuing certificates of deposit (CDs) in 2010 in order to control the monetary liquidity and redirect the cash to the money-market in two ways, namely via lending and credit. Considering that the rate of growth in total capital, reserves and provisions in the case of Jordanian commercial banks in the year 2010 reached $13.14 \%$, the growth rate in year 2011 decreased to $9.04 \%$, whereas a further decrease to $8.36 \%$ was recorded in 2012 (Association of Banks in Jordan, 2013). Furthermore, in 2009, a decision was made by the state to comply with the international accounting standards (IASs) and with the IFRS more so than in the previous years, and because the orientation of those standards is to apply the concept of fair value rather than the concept of the historical cost, which is considered to be the best measure to show the financial statement items at fair value in an efficient and active market. Since the Jordanian market does not have this feature, the latter will lead to more flawed interpretations, which are expected to facilitate the implementation of accounting conservatism.

Table 5. Regression analysis for the each year during crisis

\begin{tabular}{|c|c|c|c|c|c|c|c|}
\hline Year & Variables & $\alpha$ & $\mathrm{R}_{\mathrm{it}}\left(\beta_{1}\right)$ & $\mathrm{DR}_{\text {it }}\left(\beta_{2}\right)$ & $\mathrm{R}_{\mathrm{it}} \times \mathrm{DR}_{\mathrm{it}}\left(\beta_{3}\right)$ & $\mathrm{R}^{2}$ & Adjusted $\mathrm{R}^{2}$ \\
\hline \multirow{3}{*}{2009} & Coefficient & 2.697 & -0.212 & 0.092 & 1.102 & \multirow{3}{*}{$16.7 \%$} & \multirow{3}{*}{$13.18 \%$} \\
\hline & t-value & 0.568 & 0.493 & 0.243 & 0.693 & & \\
\hline & $\mathrm{p}$-value & 0.596 & 0.719 & 0.676 & 0.083 & & \\
\hline \multirow{3}{*}{2010} & Coefficient & 1.012 & -0.096 & 0.397 & 0.882 & \multirow{3}{*}{$39 \%$} & \multirow{3}{*}{$36.9 \%$} \\
\hline & t-value & 0.911 & 0.873 & 0.968 & 0.214 & & \\
\hline & $\mathrm{p}$-value & 0.121 & -0.178 & 0.046 & 0.383 & & \\
\hline \multirow{3}{*}{2011} & Coefficient & -3.772 & 0.210 & 0.134 & 0.421 & \multirow{3}{*}{$46.97 \%$} & \multirow{3}{*}{$45.14 \%$} \\
\hline & t-value & 0.640 & 0.683 & 0.259 & 0.140 & & \\
\hline & $\mathrm{p}$-value & -0.495 & 0.431 & 0.234 & 0.538 & & \\
\hline
\end{tabular}

Table 5 shows the coefficient of ( $\beta 3$ ) as a measure of the earnings responses to bad news compared with the good news. The results indicate that the responses for the years 2009, 2010 and 2011 are positive and insignificant, while the p-value for the years 2009,2010 and 2011 is $0.083,0.383$ and 0.538 , respectively. The results indicate that the $(\beta 3)$ is increasing over the course of the three years but does not indicate a significant change in the level of accounting conservatism for each year $(2009,2010$ and 2011). Furthermore, the level of accounting 
conservatism (adjusted R2) increased from $13.18 \%$ in 2009 to $45.14 \%$ in 2011 . It may be concluded that the level of accounting conservatism increased during the global financial crisis for the period 2009-2011, compared with the level of accounting conservatism preceding the global financial crisis for the period 2005-2008.

Table 6. Regression analysis for the period (2009-2012)

\begin{tabular}{llll}
\hline Variables & Coefficient & t-value & p-value \\
\hline$\alpha$ & 0.562 & 0.191 & 0.853 \\
$\beta_{1}$ & -0.072 & -0.382 & 0.714 \\
$\mathrm{~B}_{2}$ & 0.144 & 0.271 & 0.794 \\
$\mathrm{~B}_{3}$ & 0.858 & 0.277 & 0.030 \\
$\left(\beta_{2}+\beta_{3}\right) / \beta_{2}$ & 6.96 & & \\
$\mathrm{R}^{2}$ & 21.9 & & \\
Adjusted $\mathrm{R}^{2}$ & $17.74 \%$ & & \\
\hline
\end{tabular}

As noted in Table 6, the response coefficients of variables (DR, R $\times$ DR) and constant $(\alpha)$ during the global financial crisis were positive as expected. The results of the regression coefficient for the period 2009-2012 related to accounting conservatism show that the response of the variable coefficient ( $\beta 3$; $\mathrm{Ri} \times \mathrm{DR})$ is 0.858 with a positive and statistically significant $p$-value equal to 0.030 . The results indicate a significant change in the level of conservatism during the global crisis. In addition, the sensitivity of earnings to bad news (negative returns) is about 1 to 7 times that of the sensitivity of earnings to good news (positive returns); $(0.144+0.858) / 0.144)$ ) $=$ 6.96 for the period from 2009 up until the beginning of 2012, the sensitivity of earnings to bad news before the global crisis was 1 to 1.28 times higher. In addition, there is an increasing number of sensitivity of earnings to bad news during and after the global crisis, as shown in Figure 2. The adjusted R2 of the model is equal to $17.74 \%$, and from these results we can conclude that the level of accounting conservatism increased during the global crisis for the period 2009-2012, as shown in Figure 3.

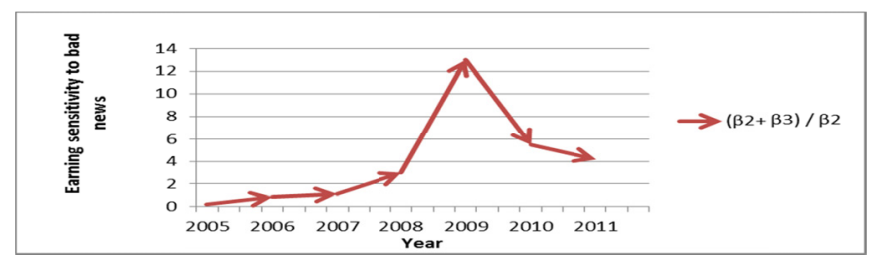

Figure 2. Earning sensitivity to bad news

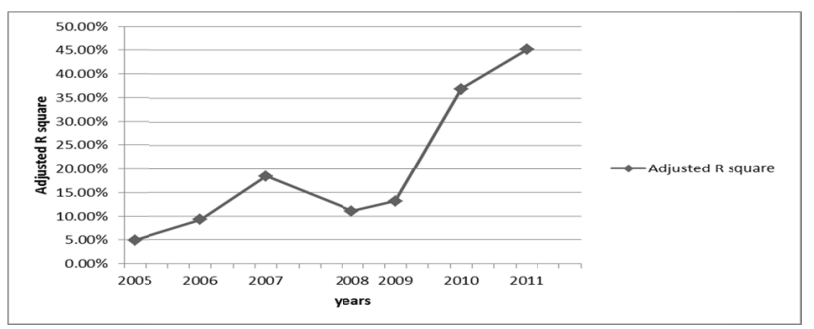

Figure 3. Level of accounting conservatism

\subsubsection{One-way ANOVA (F-test)}

F-tests were used in order to test the significant differences between the regression coefficients for the period before and during the global financial crisis. The final results presented in Table 7 show that the value of the response coefficient (B3) of variable $(\mathrm{R} * \mathrm{DR})$ is equal to 0.571 and that this value is a positive value as expected, which indicates a positive impact on profit during the global financial crisis compared with the period before the global financial crisis. The p-value is 0.040 , which indicates that there are statistically significant differences between the two periods. These results support the rejection of the null hypothesis indicating that there is no statistically significant difference in the level of accounting conservatism before the global financial 
crisis compared to the level of accounting conservatism during the global financial crisis in the case of the commercial banks in Jordan. In addition, these results are associated with the study of Sampaio (2015), which demonstrated that there is statistically significant and positive association between conservatism and crises.

Table 7. One-way ANOVA

\begin{tabular}{lllllll}
\hline & & df & Sum of Squares & Mean of Squares & F & Sig. \\
\hline \multirow{3}{*}{$\mathrm{R} \times \mathrm{DR}$} & 1 & 2.213 & 2.213 & 4.34 & 0.04 \\
& Between Groups & 77 & 41.3 & 0.497 & & \\
& Within Groups & 78 & 43.513 & & \\
\hline
\end{tabular}

\section{Conclusion}

This study aims to investigate the impact of the global financial crisis on the level of accounting conservatism in the case of the commercial banks in Jordan before and during the crisis. The sample of this study includes 78 observations; these observations are based on the financial statements of all commercial banks in Jordan and may be referred to as cross-sectional data, whereas the period from 2005 to 2011 represents a range of years characterized by time series data. The appropriate regression model to measure the relationship between cross-sectional data and time series data is in this case the pooled data regression (PDR) using the ordinary least squares (OLS) method. The results indicate that the level of accounting conservatism had been steadily increasing over a period of three years from 2005 to 2007, without indicating a significant change in the level of accounting conservatism in the years 2005, 2006 and 2007. Furthermore, the level of accounting conservatism (adjusted $\mathrm{R}^{2}$ ) increased from $4.93 \%$ in 2005 to $45.14 \%$ in 2011. With reference to the decrease in the growth rate in Jordan, the level of accounting conservatism generally remained low for the period 2005-2007. The results also indicate that the level of accounting conservatism had been steadily increasing over a period of three years during the crisis period between 2009 and 2011 compared with the level of accounting conservatism for the period 2005-2007 preceding the global financial crisis. Another result indicated that the sensitivity of earnings to bad news (negative returns) is about 1 to 7 times that of the sensitivity of earnings to good news (positive returns) for the period starting with 2009 up until the beginning of 2012, compared with the sensitivity of earnings to bad news before the global crisis which was 1 to 1.28 times that of the sensitivity of earnings to good news. The F-test was used in order to test the significant differences between the regression coefficients for the period before and during the global financial crisis. The results indicate a positive impact on the accounting conservatism and there are statistically significant differences between the two periods. We recommend that the leaders in ASE must develop a measure of conservatism and applied as a requirement to continue listing a company in ASE to increase the level of conservatism in the Jordanian shareholding companies, which will contribute to improving the credibility of financial statements, and contribute to rationalizing the investment decisions for investors and other users of financial statements.

\section{The limitations of the Study}

The research is limited by the small sample size thereof which only contained 13 banks between 2005 and 2012 . In addition, the study was conducted in the banking sector in Jordan and as a result we cannot disseminate the results of the study to other sectors or other countries. Another limitation was represented by the fact that we were not able to verify the reason behind the level of accounting conservatism related to contract incentives, debt, and tax instructions.

\section{Acknowledgments}

The authors would like to thank the Deanship of Scientific Research at Philadelphia University. Furthermore, this research was funded by the Deanship of Scientific Research at Philadelphia University.

\section{References}

Amman Stock Exchange. (2016). About ASE. Retrieved from: http://www.ammanstockexchange.net/

Balakrishnan, K., Watts, R., \& Zuo, L. (2016). The Effect of Accounting Conservatism on Corporate Investment during the Global Financial Crisis. Journal of Business Finance \& Accounting, 43(5-6), 513-542. http://dx.doi.org/10.1111/jbfa.12206.

Basu, S. (1997). The conservatism principle and the asymmetric timeliness of earnings1. Journal of Accounting and Economics, 24(1), pp.3-37. http://dx.doi.org/10.1016/s0165-4101(97)00014-1

Bryman, A., \& Bell, E. (2015). Business research methods. Oxford University Press, USA. 
Chung, H. H., \& Wynn, J. P. (2008). Managerial legal liability coverage and earnings conservatism. Journal of Accounting and Economics, 46(1), 135-153. http://dx.doi.org/10.1016/j.jacceco.2008.03.002

Ettredge, M., Huang, Y., \& Zhang, W. (2012). Earnings restatements and differential timeliness of accounting conservatism. Journal of Accounting and Economics, 53(3), 489-503.

Financial Accounting Standards Board (FASB). (1980). Conceptual Framework for Financial Reporting: Objective of Financial Reporting and Qualitative Characteristics of Decision-Useful Financial Reporting Information, Preliminary View, Norwalk, (CT:FASB). Retrieved from http://www.fasb.org

Francis, B., Hasan, I. \& Wu, Q. (2013). The Benefits of Conservative Accounting to Shareholders: Evidence from the Financial Crisis. Accounting Horizons, 27(2), 319-346. http://dx.doi.org/10.2308/acch-50431

Gul, F. A. A., Srinidhi, B., \& Shieh, T. (nd.). The Asian Financial Crisis, Accounting Conservatism and Audit Fees: Evidence from Hong Kong. SSRN Electronic Journal. http://dx.doi.org/10.2139/ssrn.315062.

Hamdan, A. M. M. (2011). Evaluation of the Conservatism Level in Kuwait Stock Exchange: By Using Basu Model. Journal of Modern Accounting and Auditing, 7(4), 391.

Hamdan, A. M. M. (2012). Factors affecting accounting conservatism when preparing corporate financial reports: Evidence from Jordan. Jordan Journal of Business Administration, 8(1).

Heijden, R. J. J. Van Der. (2011). Accounting Conservatism and the crisis: What was the impact of the credit crisis on conservatism? (Unpublished master's thesis). Erasmus University Rotterdam, Master Thesis.

Herrmann, D. R., Pornupatham, S., \& Vichitsarawong, T. (2008). The impact of the Asian financial crisis on auditors' conservatism. Journal of International Accounting Research, 7(2), 43-63. https://doi.org/10.2308/jiar.2008.7.2.43

Khan, M., \& Watts, R. L. (2009). Estimation and empirical properties of a firm-year measure of accounting conservatism. Journal of Accounting and Economics, 48(2-3), 132-150. http://dx.doi.org/10.1016/j.jacceco.2009.08.002.

Man, C., \& Wong, B. (2013). Corporate Governance And Earnings Management: A Survey Of Literature. Journal of Applied Business Research (JABR), 29(2), 391. http://dx.doi.org/10.19030/jabr.v29i2.7646

Mohammed, A. A. (2011). An analytical study for the effect of accounting conversatism on the published financial lists, Bani Swaif University. Scientific Journal, 51, 17.

Sampaio, T. C. Q., Coelho, A. C., \& Holanda, A. P. (2015). Adoc? o de conservadorismo nos lucros em periodos de crise financeira: evidencias no Brasil. Enfoque, 34(1), 71.

The Jordanian associated of bank. (2016, October13). Development of the Jordanian Banking sector. Retrieved from http://www.abj.org.jo/en-us/developmentofthejordanianbankingsector.aspx

Vichitsarawong, T., Eng, L. L., \& Meek, G. K. (2010). The Impact of the Asian Financial Crisis on Conservatism and Timeliness of Earnings: Evidence from Hong Kong, Malaysia, Singapore, and Thailand. Journal of International Financial Management \& Accounting, 21(1), 32-61. http://dx.doi.org/10.1111/j.1467-646x.2009.01035.x

Warganegara, D., \& Land., V. V. (2010). The effects of the Asian financial crisis on accounting conservatism in Indonesia. Asian Academy of Management Journal of Accounting and finance, 6(1), 69-88.

\section{Copyrights}

Copyright for this article is retained by the author(s), with first publication rights granted to the journal.

This is an open-access article distributed under the terms and conditions of the Creative Commons Attribution license (http://creativecommons.org/licenses/by/4.0/). 